\title{
Farmers' Household Empowerment in Entikong, West Kalimantan, Indonesia
}

\author{
Kardius Richi Yosada ${ }^{1}$, Ery Tri Djatmika $^{2}$, Budi Eko Soetjipto ${ }^{2} \&$ Hari Wahyono $^{2}$ \\ ${ }^{1}$ Graduate School, Universitas Negeri Malang, Indonesia \& STKIP Persada Khatulistiwa Sintang, Indonesia \\ ${ }^{2}$ Faculty of Economics, Universitas Negeri Malang, Indonesia \\ Correspondence: Ery Tri Djatmika, Universitas Negeri Malang, Indonesia. E-mail: ery.tri.fe@um.ac.id
}

Received: September 3, 2017

doi:10.5539/jsd.v10n6p254

\begin{abstract}
This paper aims at analyzing current situation in Entikong as a border region of Indonesia-Malaysia. Economically, this region is dominated by agricultural sectors and mostly harvested valuable commodities were traded in border by farmers from Entikong. This study employed a phenomenological qualitative approach for describing problems faced by farmers and the efforts related to farmers' household empowerment for improving their quality of life. The data were collected through observation, interview, and documentation, and it was analyzed by using the steps of verification and triangulation, data reduction, data display, and conclusion drawing. The findings revealed that main problems are related to the insufficiency of socio-economic infrastructures for improving value added for agricultural products, such as the limitation of roads infrastructure and far distance of market make farmers unwilling to sell their harvested products because of high distribution expenses. Farmers empowerment done by government and NGO were directed to improve their knowledge and skills related to plantation and agricultural activities. Moreover, it needs socio-economic institutional strengthening and participation from farmers' community as well.
\end{abstract}

Keywords: farmers' household empowerment, valuable commodities, Border Area, West Kalimantan

\section{Introduction}

Potential utilization of existing resources and mainly natural resources in border area of a nation becomes a concern because of economic and non-economic value. It has a uniqueness in the form of spatial closeness (van Well, 2005; Niebuhr and Stiller, 2001), specifically in the border of Indonesia-Malaysia in Entikong, West Kalimantan. Relationship among people live in Entikong can be seen in social, economic, and cultural life. It occurs because of the similarities among ethnic groups where they are from Dayak Iban, Dayak Baduyu, Dayak Kahayan, and a small number of Malaysian. Formerly, the ethnic of Dayak generally had been staying along the border, and they had been living in groups spread out area, and sometimes that their settlement did not adhere to administrative rules of both countries (Yosada, et al., 2016). That condition has been subjected to change as a result of the efforts of each country to control the administration.

Previous research findings revealed that Malaysia is better than Indonesia in utilizing its potential economic resources in terms of trading between those two countries. The study of Ishaq (2011) showed that there are many impoverished people in Entikong subdistrict, and some of them opened pedestrian retail stands to sell consumer goods which most of products are from Malaysia. People are more familiar with products from Malaysia because of it is easiness to obtain and also cheap. Moreover, research finding (Raharjo, 2013) revealed that majority of people living in Entikong are farmers, and they sell agricultural products, such as pepper and peanuts to Malaysian traders. Farmers prefer to sell their agricultural products to Malaysian border because it is closer and the price is quite competitive, which implies that agricultural sectors activities in Entikong much more be determined by them. It is realized that how important is the empowerment of farmers household not to be dependent on other parties in determining production of economically valuable commodities in agricultural sectors.

It is understood that in border region, trading of agricultural products economically has positive impact on farmers' household life. There is positive value of local export-import trading between two areas for local communities for fulfilling the needs of households' everyday life mainly for farmers' families. The problem is 
that the farmers have inferior position to bargain in terms of perishable non value added agricultural products traded. Besides, they have enough time that can be used for productive purposes between the season of planting and harvesting. In relation to uplifting farmers' household welfare, it needs sustainable empowerment program for farmers, so they are able to use time effectively for economic manners, and also it is expected to be able to increase the economic value for their valuable agricultural products such as pepper, latex, cocoa, palm oil, and rice (Yosada, et al., 2016).

Empowerment program for farmers' household that enable them to having bargaining position of valuable commodities traded and also enable them to use the time for productive activities can be an important point for economic development in the border area. It is expected that the program is able to improve farmers' families welfare, through enhancing their economic competitiveness. Then, how is the farmers' household empowerment in Entikong, West Kalimantan as the border region of Indonesia-Malaysia?

\section{Literature Review}

\subsection{Empowerment}

Empowerment is an effort and activity to uplift skills, knowledge, and power of intended community to affect their lives and the lives of others, to be independent and more important thing to make them capable to lift up from poverty. It can be carried out through active engagement of the community facilitated by skillful trainers (Widjajanti, 2011; Kurniawati, et al., 2013; \& Ulumiyah, et al., 2013). In facilitating people, the first to do is called enabling process means creating and maintaining climate for them to think possible potential resources to develop including the potential of natural and human resources. The second, it is to look for the possibility to increase its potential values for economically beneficial either to gain higher appreciation or higher value added. Finally, it is called continuing the process of empowerment through self-sustainable improving capability to be able to adjust in dynamic changing circumstances (Sumodiningrat, 1999). Moreover, the study of Lord and Hutchison (1993) found that the interdependence relationship during empowerment process can be seen as an important part how the member of community relates each other. The result showed that the empowerment process much more powerful if there is mutual interaction of individuals within the community.

\subsection{Valuable Commodity}

Most of valuable commodities traded in Entikong border region are agricultural products. From local community perspective, trading of agricultural commodities is quite potential and important to support people living. If it is compared to trading in southern part of Entikong that needs extra expense for transportation, trading to northern part of border area is very competitive seen from production cost point of view. From another point of view, it is also a problem showing that they have no other choice to trade. It is a kind of weakness that makes the price offered of products sold is low, and it is much more determined by brokers or buyers. Although some problems occurs, seen from the perspective of how local community living is, products from agricultural sectors are quite essential and takes part as valuable commodities for the society (Arifin, 2013).

As a consequence of geographical position, each area in the globe has specific natural advantage mainly in agricultural sector that is able produce commodities which cannot be produced in other areas. Valuable agricultural commodities produced and traded in Entikong border are also have competitive advantage in terms of its competitive price. This condition is very beneficial when facing tight market global competition (Tambunan, 2001). In the context of community development, competitive advantage in agricultural sectors owned by community and available in specific area can be considered as a strategic and entry point for policy implementation. The purpose is related to regional economic development and growth, and accordingly agricultural sectors in Entikong are potentially to be developed for regional growth (Yulianto and Santoso, 2013).

\subsection{Border Region}

Border region is a territorial where two or more engaged countries need to attend for providing specific attributes related to geographical characteristics. In border where there is community of people living in both countries interact each other, the fulfillment of necessities can be in the form of either physical or psychological needs. The border region requires a special touch in development process since it involves people who have possible different ideology and way of life. Therefore, knowing typology and social characteristics of community with its cultural life is required before taking and implementing specific economic development policy which has to be relevant.

Typology is taken to classify characteristics in such way for the use of border areas development. It could be described the characteristics based on economic life, social networking, employment, institutions, levels of education, and other relevant characteristics. The purpose of classification is to provide enough information 
before implementing developmental policies (Wu, 2001). Mechanism process can be started by identifying different functional and spatial characteristics considered into economic development area (Gonzalez, 2001). The efforts implemented by the government in conducting development are directed to protect and manage border region, to utilize sustainable natural resources, and to maintain the national integrity of the area (LAN, 2004). Those efforts need public participation.

Regional managerial actions in border areas need to be focused on two approaches in terms of security and welfare (Raharjo, 2013). The security approach is government's effort to protect and to secure local communities from threats either physically or psychologically from irresponsible parties, and also from natural disaster. While the welfare approach is the effort to promote a better life for the community through improving economic, prosperity, and health standards.

\section{Research Method}

This study used phenomenological qualitative approach. The data were collected by using observation, in-depth interview, and exploring archive documents. The observation was conducted through participatory research where observer took place in daily life of people. The interview was conducted through conversation with key informants who were mostly from public figures that consist of sub-district heads, village heads, neighbourhood heads, hamlet or rural community heads, the chairman of NGO "Anak Bangsa", and also data taken from people in community. The documentation was used to take data from archive available either in public government institutions such as Regional Development Planning Agency or in non-government organization.

The field of research was located in the border of Entikong, Sanggau, West Kalimantan Province. The data were analyzed by using steps of data collection, data reduction, conclusions, verification, and presentation of data (Miles and Huberman, 1984). Furthermore, it was followed by checking the validity of the findings, and conducting triangulation as an attempt to take look of phenomenon from different angles, verifying findings by using various sources of information and techniques.

\section{Research Findings}

Research findings include three parts: development program of valuable commodities, farmers' household empowerment, and role of local government in the empowerment.

\subsection{Development Program of Valuable Commodities Business}

There were several types of valuable commodities in Entikong that involve pepper, latex or rubber, cocoa, oil palm, and paddy or rice. The coverage area used for plantation was more or less 11,372.87 Ha. From field research, it was found that the society needs a kind of production and supporting facilities. Production facility could be in the form of infrastructure for agricultural sectors that was very limited, such as the availability of tertiary irrigation canals, supply of water for irrigation, and also road for commodities transportation. Moreover, market infrastructure built in Sanggau, West Kalimantan was not occupied by traders caused by geographically limited to access.

Meanwhile, regarding the condition of agriculture in the border area of Entikong subdistrict generally, it showed that there were insufficiency of agricultural production facilities used, limited availability of certified seeds, fertilizers, and pesticides, agricultural machineries. It is also limited of tertiary irrigation canals for paddy fields. Furthermore, the level of cultivation technology used, and the appropriateness of cultivation skills and knowledge is also very limited. There was also absence of training and socialization activities for farmers, in terms of the way of nursery, cultivation, pesticide management, and post-harvest management. In post-harvest, agricultural products are only sold in the form of natural raw materials, so there is additional value because of the absence of agricultural machineries for processing appropriately.

\subsection{The Need of Supporting Facility}

The presence of agricultural institutions was expected by farmers. It could drive business development, and in turn it could increase farmers' family income. Groups of farmers and village cooperative unions (locally called KUD, it is abbreviation for Koperasi Unit Desa) were expected to able to facilitate and fulfill the needs of farmers, including information about commodities market price. It was found that local farmers need information about modernization in agricultural sectors from agricultural field official elucidators. They were responsible for providing information about agricultural techniques and insights for farmers about newness in agricultural fields. Furthermore, driving factor to develop agricultural sectors is the function of government institutions at local level to work cooperatively. At the level of farmer, their participation can be encouraged through groups of farmers. Well-structured farmers' group is one of social capital that can be utilized effectively to develop agricultural sectors in Entikong. 


\subsection{Society Empowerment}

It was found that society empowerment in border area was necessary for improving quality of life. From field study, it was revealed that the frequency of economic empowerment for farmers was very limited. The empowerment was provided by non-governmental organizations and also given by Indonesian workers who had worked in Malaysia. The empowerment was also directed to family members of farmers related to the use of time to be more productive. These could be in the form of developing skills in the area of weaving, crafting, cooking, and planting. There are some consequences of people living in remote area, limited access of information, and limited empowerment activities for farmers' families, such as their agricultural skills are far behind compared to farmers living in Malaysia border, and most of traders who had better information access are from Malaysia.

It was revealed that empowerment is essential for farmers in the border. It was necessary to empower farmers' economic life. It is expected that they are able to be self-reliance to fulfill daily life primary needs and to be able to use their leisure time effectively for productive purposes. Active participation of the community is also potential for introducing new business activities, and it is also potential to change mindset of people about productive economic activities. The main purpose is to achieve society welfare and wellbeing. The model of empowerment developed to accelerate the development in Entikong was related to the development of education and skills to be independent by using potential resources available in the region. Developing education and skills means that there is a need for cooperation among them to participate in sustainable development process.

Most of people living in Entikong were graduated from primary education. Unfortunately, phenomenon showed that the quality of education did not fulfill the expectation. Very limited people spent their income for human capital investment. However, it also could be caused by limited demand for qualified human resources as the impact of work availability was only in agricultural sectors. The lack of demand for qualified human resources in turn it caused slow economic development, and dependency of work fields were still on agricultural sectors and mostly it depend on nature and traditional living. Farmers' empowerment process should ideally be conducted through assistance with the spirit of capacity reinforcement, both for intended communities and economic institutions. Most essential part of empowerment called capacity building was the effort to improve knowledge and skills for human involved, and to improve the existence of business institutions that economically support the life of people.

\subsection{The Role of Government in Farmers' Empowerment}

Field study revealed that cooperation and coordination among government institutions were very rare, such as how to manage forest plantation that did not involve and coordinate with people who live surround the forest. It was also happen to companies that operated the plantation where they did not coordinate with and provide enough information to people living in the place. Besides, there was overlapping role and function among institutions that lead to confusion in the society when they are dealing with them such as how to handle problems occurred caused by limited information possessed. The role of government in community development was still limited to the trade.

It was expected by society that institutional reinforcement and development conducted by government should incorporate society participation. The government should develop local policy setting, decide priority scale, determine guidelines, norms, standards, procedures, and criteria for regional development that involve society participation to coordinate. Moreover, it was also expected that the government should coordinate and facilitate society organizations for reinforcement and empowerment. Then, it is expected that the activities are followed by monitoring, evaluation, and reporting concerning program implementation. Coverage of programs has to include economic empowerment mainly for farmers' family, small business development, rural micro finance institution development, and agricultural products distribution. The source of funding can be financed either by central or local at provincial and regency levels as investment for social capital development (Bappeda, 2014).

\section{Discussion}

\subsection{Business Development of Valuable Commodities}

Research findings revealed that the main business development program needed and suitable for for people, specifically farmers' families who live in Entikong where is located in border region is to provide agricultural production facilities. Such facilities include: (1) repairing and improving dams and irrigation channels to support agricultural sectors; (2) providing good grade agricultural seeds locally, and if it is possible through the establishment of seedbed center; (3) establishing agricultural kiosks that sell agricultural production facilities such as fertilizers, pesticides or hormones needed to increase the agricultural production, either provided by 
private or agricultural co-operatives; (4) providing agricultural tools and machines suitable to be operated in rural areas; (5) providing processing tools for processing agricultural harvested products by farmers.

Furthermore, it needs also attention on developing agricultural skills, managerial capabilities and technological know-how for farmers. These include activities in training given to farmers how to use cultivation technology, to exterminate rats and plant diseases, to distribute effectively and efficiently valuable commodities harvested, and to add value for post-harvested agricultural commodities for fulfilling the market demand. Likewise, farmers need elucidating programs to enrich their knowledge related to cultivation and management of agricultural business sectors. This finding is relevant with the study of Ishaq (2011) who revealed that many poor people lived in Entikong caused by limited access of infrastructure, health services, and educational services. The study of Husin (2009) also found that productivity of agricultural business was positively affected by quality of service and facilities to support its sustainable improvement. Current situation shows that the presence of Local State-Owned Business (called BUMDes, it is abbreviation for Badan Usaha Milik Desa) Agropotombuluh, Ltd. that provides agricultural facilities and services has increased agricultural productivity. It is expected that the role of such enterprise is able to be extended and improved in terms of the coverage of services provided for farmers, and more support given by the central government for the existence of BUMDes. So, in turn it is able to contribute on farmers' productivity.

\subsection{Society Empowerment by Developing Valuable Commodities}

In this region, most of people are living as farmers, and only small part of them worked in trade and services sectors. Therefore, attention of all parties is essential, either from central, provincial, or regency government to arrange for farmers' empowerment. Grouping of farmers is seen as effective and efficient way for conducting empowerment. Farmers can be divided into groups based on kinds of agricultural commodities planted. Agricultural crops are planted based on similarity of location areas. Within the same area is planted the same plantation. So, it is effective and efficient if farmers' empowerment is based on the similarity of location of living. Besides, for developing their agricultural business sufficiently, farmers need technical assistance related to access for capital resources. Financial institutions need to be introduced to them, and they need to know credible resources of funds that finance agricultural sectors. To support agricultural sectors in borders, central government through Ministry of State-Owned Enterprise is able to establish financial institutions either in the form of banks or union co-operatives at sub-district areas to omit geographical barriers for farmers to access.

Third business parties were also took important part mainly they buy agricultural products harvested in border region. Moreover, in the near future it is expected that there will be small-scale factories are able to be built by private sectors to add value for agricultural products. This will happen if the economic infrastructure supports the existence of those factories. The value added of agricultural products is essential for the improvement of regional domestic income. Many small-scale factories are able to be built based on agricultural sectors as potential economic in border region. Those small-scale factories are needed to add value for agricultural products for improving farmers' quality of life such as palm oil factory, production processing for cocoa, and production processing for latex or rubber. It is also required to build vocational agricultural schools to provide educational opportunity for young generation in border region appropriately suitable with their socio-economic potential. By providing educational opportunity, it will support directly to the availability of medium skilled labor to support agricultural sectors, and to improve socio-economic status indicators. It is relevant with the study of Kurniawati, et al. (2013), Gevisioner, et al. (2013), and Ojiagu, et al. (2015) that society empowerment programs have to incorporate resources available in society into programs developed by government and possible private sectors, so that the society will gain sustainable impact.

\subsection{The Role of Government}

The government has already issued regulation no. 30/2007 concerning rural development. It is intended to develop agriculture for increasing food security, to facilitate environmental conservation, to regulate the use of rural and coastal areas, to facilitate the development of rural infrastructure, to facilitate need assessment mapping to the use of technologies, and to coordinate the cooperation of technologies used in rural areas. Border management agency has a responsibility to establish border development program policy. These include setting amount of budget required, coordinating and carrying out program implementation, and supervising and evaluating of program implementation.

One of essential regulation is related to space management. The area of Entikong is $506.89 \mathrm{~km}$ square, and it is only 13,758.98 Ha used for living and economic activities, and the rest are for conservation treated as protected areas. Related to the used of land, the government has clustered agricultural sectors based on kinds of plantation. For instance, in the area of Nekan sub-district is allocated for paddy field and non-irrigated plantation. While, in 
Southern Entikong and Semanget sub-districts are allocated for latex (Bappeda, 2011). Geographically located in border region between Indonesia and Malaysia, Entikong has a central point to consider. It is necessary to provide special facilities to serve people live in the border as mentioned in national regional planning (BNPP, 2010).

Main problem in the border region is that many sub-districts have not been connected with roads, and most of people use river transportation. In many places, there are conservation areas between sub-districts, so it is a problem for developing roads on those areas. The availability of roads is essential for agricultural products distribution and community access. Current situation shows that inter-village areas are connected with concrete paved for pedestrian and motor cycle transportation. The existence of appropriate roads infrastructure for 4 or 6 wheels vehicles for transporting agricultural products are essential for improving added value harvested commodities (BNPP, 2010). The presence of roads infrastructure are considered as locomotive for national and regional development, and it is important for supporting the improvement of welfare and quality of life of the community, and the key point for economic productivity (Atmaja and Mahalli, 2015). Research finding shows that the limited infrastructure availability restricts farmers' decision to trade their harvested agricultural products.

Another important point for improving farmers' family welfare is the availability of educational institution facilities, local government clinic institutions to serve general health check, local government administrative services, and local market to serve daily needs. The availability of those facilities are needed at least one for each sub-district, because people face problems with geographical distance and roads infrastructure. It is relevant with the study of Srebro and Maxim (2006) that the government has to have concern with life management and government administrative works for the citizens mainly living in the border region. Moreover, Marwasta (2016) pointed out that the border region in Indonesia is very large and lack of social and physical infrastructures require adequate management system organized integrally.

\section{Conclusion}

There were many valuable agricultural commodities available in Entikong that include pepper, latex, cocoa, palm oil, coffee, and rice. Those commodities were traded in border region as harvested products without additional processed and no value added. Rural development programs implemented in Entikong included empowerment for farmers intended to support agricultural sectors, mainly by fulfilling production and supporting facilities. At the level of farmers, active participation of them can be encouraged through institutions by using farmer groups.

Farmers household empowerment have been done to accelerate the development in the border area in terms of development of education and ability to become independent society such as the capability to process harvested agricultural commodities and to live in better by maintaining environment sustainably. Since beginning, the empowerment process should engage their participation and be conducted ideally through sustainable technical assistance.

The roles of government in valuable commodities development program consist of making guidelines, norms, standards, procedures, and criteria for institutional reinforcement and development of farmers' participation. To carry out these obligations, central government, West Kalimantan government, and districts governments within the province should be responsible for coordinating, facilitating, implementing, monitoring and evaluating each program activity.

\section{References}

Arifin, B. (2013). On the Competitiveness and Sustainability of the Indonesian Agricultural Export Commodities. ASEAN Journal of Economics, Management and Accounting 1(1), 81-100.

Atmaja, H. K., \& Mahalli, K. (2015). Pengaruh Peningkatan Infrastruktur terhadap Pertumbuhan Ekonomi di Kota Sibolga. Jurnal Ekonomi, 3(4), 250-265.

Bappeda-Badan Perencanaan Pembangunan Daerah Kabupaten Sanggau, Kalimantan Barat, Indonesia. (2011).

Bappeda-Badan Perencanaan Pembangunan Daerah Kabupaten Sanggau, Kalimantan Barat, Indonesia. (2014).

BNPP-Badan Nasional Pengelolaan Perbatasan. (2010). Desain Besar Pengelolaan Batas Wilayah Negara dan Kawasan Perbatasan Tahun 2011-2025. Jakarta: BNPP.

Gevisioner, Bangun, R., \& Karyanti. (2013). Strategi Pembangunan Berbasis Masyarakat di Kecamatan Perbatasan Negara di Provinsi Riau. Jurnal Bina Praja., 5(1), 53-62. https://doi.org/10.21787/JBP.05.2013.53-62

Gonzalez, P. W. (2001). New Strategies of Transborder Regional Development. In Edgington, David W. et al. 
(Eds.), New Regional Development Paradigms, 2 (pp. 57-59). London: Greenwood Press.

Husin, S. (2009). Analisis Faktor-faktor yang Mempengaruhi Produktivitas Usahatani dan Pengaruhnya terhadap Kepuasan Petani (Studi Kasus Bumdes PT. Agropotombuluh di Kecamatan Telaga Biru Kabupaten Gorontalo). Unpublished Thesis. Jakarta: Program Magister Perencanaan \& Kebijakan Publik, Fakultas Ekonomi, Universitas Indonesia.

Ishaq, M. (2011). Pembinaan Nasionalisme Pemuda Perbatasan Melalui Program Pendidikan Luar Sekolah. Jurnal Ilmu Pendidikan, 17(6), 459-468.

Kurniawati, D. P., Supriyono, B., \& Hanafi, I. (2013). Pemberdayaan Masyarakat di Bidang Usaha Ekonomi (Studi pada Badan Pemberdayaan Masyarakat Kota Mojokerto). Jurnal Administrasi Publik (JAP), 1(4), 9-14.

LAN-Lembaga Administrasi Negara. (2004). Kajian Manajemen Kawasan Perbatasan Negara. Laporan Penelitian, Pusat Kajian Administrasi Internasional. Jakarta: LAN.

Lord, J., \& Hutchison, P. (1993). The Process of Empowerment: Implications for Theory and Practice. Canadian Journal of Community Mental Health, 12(1), 5-22. https://doi.org/10.7870/cjcmh-1993-0001

Marwasta, D. (2016). Pendampingan Pengelolaan Wilayah Perbatasan di Indonesia: Lesson Learned dari KKN-PPM UGM di Kawasan Perbatasan. Indonesian Journal of Community Engagement, 1(2).

Miles, M. B., \& Huberman, A. M. (1984). Qualitative Data Analysis: A Sourcebook of New Methods. California: SAGE publications Inc.

Niebuhr, A., \& Stiller, S. (2001). Integration Effect in Border Regions - A Survey of Economic Theory and Empirical Studies. HWWA Discussion Paper Hamburg.

Ojiagu, N. C., Onugu, C., \& Uchenna. (2015). Effects of Membership of Cooperative Organizations and Determinants on Farmer members' Income in Rural Anambra State, Nigeria. International Journal of Scientific \& Technology Research, 4(8), 28-35.

Profil Kecamatan Entikong, Kalimantan Barat, Indonesia. (2014).

Raharjo, S. N. I. (2013). Kebijakan Pengelolaan Kawasan Perbatasan Darat Indonesia-Malaysia (Studi Evaluatif di kecamatan Entikong). Widyariset, 16(1), 73-80.

Srebro, H., \& Shoshani, M. (2006). Towards a Comprehensive International Boundary Making Model. Paper presented in Shaping the Change XXIII FIG Congress, Munich, Germany, October 8-13, 2006.

Sumodiningrat, G. (1999). Pemberdayaan Masyarakat dan Jaring Pengamanan Sosial. Yogyakarta: Ghalia Indonesia.

Tambunan, T. (2001). Perdagangan Internasional dan Neraca Pembayaran, Teori dan temuan Empiris. Jakarta: LP3ES.

Ulumiyah, I., Gani, A. J. A., \& Mindarti, L. I. (2013). Peran Pemerintah Desa dalam Memberdayakan Masyarakat Desa (Studi pada Desa Sumberpasir Kecamatan Pakis Kabupaten Malang). Jurnal Administrasi Publik (JAP), 1(5), 890-899.

Van Well, L. (2006). Cross-Border Typologies in the Enlargement Area. Results from the ESPON 1.1.3 Report. Enlargement of the European Union and its Polycentric Spatial Structure. Royal Institute of Technology.

Widjajanti, K. (2011). Model Pemberdayaan Masyarakat. Jurnal Ekonomi Pembangunan, 12(1), 15-27. https://doi.org/10.23917/jep.v12i1.202

Wu, C. T. (2001). Cross-border Development in a Changing World: Re-defining Regional Development Policies. In D. Edgington, A. Fernandez, \& C. Hoshino (Eds.), New Regional Development Paradigms (Vol. 2, pp. 21-38). New Regions, Concepts, Issues and Practices. Westport: Greenwood Press.

Yosada, K. R., Wardhana, E. T. D. R. W., Soetjipto, B. E., \& Wahyono, H. (2016a). Developing The Border Area of Entikong In the Perspective of Economy. Paper presented in the $1^{\text {st }}$ International Conference on Economic Education and Entrepreneurship 2016, Proceeding, Faculty of Economics, Universitas Negeri Surabaya.

Yosada, K. R., Wardhana, E. T. D. R. W., Soetjipto, B. E., \& Wahyono, H. (2016b). The Feasibility of Economic Potential for the Improvement of Public Welfare in Indonesia-Malaysia Border in Entikong. International Journal of Research \& Review, 3(12), 40-49.

Yulianto, D. P., \& Santoso, E. B. (2013). Identifikasi Potensi Komoditas Unggulan Pada Koridor Jalan Lintas 
Selatan Jatim di Kabupaten Tulungagung-Trenggalek. Jurnal Teknik Pomits, 2(2), C118-C122.

\section{Copyrights}

Copyright for this article is retained by the author(s), with first publication rights granted to the journal.

This is an open-access article distributed under the terms and conditions of the Creative Commons Attribution license (http://creativecommons.org/licenses/by/4.0/). 